\title{
Corporate Governance Disclosure and Financial Performance of Deposit Money Banks in Nigeria
}

\author{
ThankGod C. Agwor and Njokuji Ignatius Amuchechukwu
}

\begin{abstract}
Given that a key mechanism of corporate governance is corporate disclosure, this study, anchored on agency theory and stakeholder theory, examined the effect of corporate governance disclosure on the financial performance of deposit money banks quoted on the Nigeria Stock Exchange. Based on the provisions of the Code of Corporate Governance for Public Companies in Nigeria, 2011 and the Code of Corporate Governance for Banks and Discount Houses 2014, the study developed a disclosure checklist and employed content analysis method to extract corporate governance from 78 annual reports of thirteen Nigerian deposit money banks from 2011 to 2016. The study categorized corporate governance disclosure into three - corporate governance disclosure on board of directors, corporate governance disclosure on risk framework, and corporate governance disclosure on whistle blowing policy. It constructed an overall corporate governance disclosure index as well as sub-indices corresponding to the three categories of corporate governance disclosure. The study formulated ten hypotheses and ranked ordinary least square methods of multiple regressions to explore the relationship between corporate governance disclosure and the financial performance of deposit money banks in Nigeria. The result showed a positive and significant association between overall corporate governance disclosure and the financial performance of deposit money banks in Nigeria. The result of the OLS regressions also supported a positive effect of corporate governance disclosure on board of directors and whistle blowing policy on the financial performance of the deposit money banks in Nigeria. Contrary to expectation, the study failed to document a significant association between corporate governance disclosure on risk framework and financial performance of deposit money banks. This study has contributed empirically to the body of knowledge by providing broader understanding of the effect of corporate governance disclosure on the financial performance of a critical sector of the Nigerian economy. Methodologically, the study is one of the few that developed disclosure checklist based on the provisions of both codes of corporate governance of Securities and Exchange Commission and Central bank of Nigeria and employed ranked OLS.
\end{abstract}

Index Terms - Corporate Governance Disclosure, Disclosure index, Risk Framework, Whistle Blowing Policy.

\section{INTRODUCTION}

The stability of the financial system has assumed a greater focus as a key objective of economic policy in both developed and developing countries. This is borne out of globalization and technological advancement which moves at tsunami rate globally, with its attendant challenges

Published on October 30, 2020.

ThankGod C. Agwor, Rivers State University, Nigeria

(corresponding e-mail: tagwor@yahoo.com)

Njokuji Ignatius Amuchechukwu, Rivers State University, Nigeria. especially in the financial sectors of nations. Financial regulators everywhere are scrambling to assess the changes and master the [1], [2].

In view of the above assertions, and following the series of financial scandals and the collapse of corporate institutions around the world, corporate governance has been given a great deal of attention and has become a topical issue among scholars in the last decade. Accounting scandals and corporate governance failures have been linked to corporate collapses [3] Notable among these shocking corporate collapse are Enron, the Houston, Texas based energy giant, WorldCom the telecom behemoth, One Tel(Australia), Notel (Canada), Cadbury (Nigeria). The banking sector has also witnessed cases of collapse. In Nigeria we have the cases of Savannah Bank Plc, Oceanic Bank Plc, Afribank Plc, Societe General Bank Ltd and the recent case of Skye Bank Plc. The cases of banking sector collapse in Nigeria has been serial in nature. There are also cases of banking collapse in other developing economies. The Imperial Bank limited, Dubai Bank Limited and Chase bank Limited, all in Kenya and the recent consolidation of BEIGE, Sovereign, Construction, Unibank and Royal bank in Ghana into Consolidated Bank of Ghana Limited.

In the past few years' corporate governance issues in all sectors of the Nigerian economy have become a burning issue. It is believed that for advancement and lasting performance in financial and operating terms to occur, there must be accountability and transparency. This has led to different reforms, improvements, and continuous review of corporate governance practices of firms. These reforms take the form of either enactment of new laws or issuance of code of good corporate governance practices. One Agency that has been in the fore front of transparency and Accountability in Nigeria is The Security and Exchange Commission. The Securities and Exchange Commission of Nigeria issued the code of corporate governance in 2003, with a revision in 2011. Equally there are industry specific codes of corporate governance in Nigeria. These are Code of corporate governance for banks in Nigeria post consolidation, effective April 2006 issued by Central bank of Nigeria, with a revision in 2014, the Code of corporate governance for licensed pension operators issued by the National Pension commission in 2008, the Code of corporate governance for insurance Industry in Nigeria issued by the National Insurance commission in 2009. These codes set out the provisions which if applied with diligence and transparency will ensure accountability that would maximize shareholders' wealth.

Effective corporate governance practices provide a structure that works for the benefit of stakeholders by ensuring that the enterprises adhere to accepted ethical 
standards and best practices as well as formal laws (CBN, 2014). Corporate governance refers to the processes and structures by which the business and affairs of institutions are directed and managed in order to improve long term shareholders' value by enhancing corporate performance and accountability, while taking into account the interest of other stakeholders [4]. Corporate governance focuses on accountability mechanisms that govern the relationship among shareholders, board of directors, senior management, the workers, and the stakeholders [5]. It essentially involves balancing the interest of shareholders, stakeholders, community, management, suppliers, financiers, and the government. It encompasses every spheres of management entailing creating a balance among the goals of all stakeholders", be it economic, social, and political goals

Deposit money banks play a crucial role in the functioning and development of any nation. In Nigeria, the banking industry is a dominant player in the financial service industry which accounts for about $60 \%$ of the Gross Domestic Product (GDP) of the nation. Being a developing nation, whenever there is problem in the banking industry, it dis-orientates the entire economic system and holds back the nation's planned economic development. Again, the deposit money banks play a vital role in the economic development of Nigeria by providing the platform for payments and deposit mobilization from the surplus units for onward lending to the deficit units.

The deposit money banks also drive the activities of the Nigeria Stock Exchange and the collapse of any deposit money bank is likely to generate contagion effect which will be disastrous to the economy. Moreover, firm performance plays critical role in firm valuation and stewardship report, firm financing, and general operating decisions [6]. Thus, studying the link between the performance of deposit money banks and corporate governance disclosure practices is of public interest.

Deposit money banks are always at the heart of the worlds' financial crises, including the last global economic meltdown. There is deterioration of their asset portfolios worsened by fraudulent acts of presenting false financial statements and lack of adherence to the corporate governance principles [3].

The regulators assemble the best guidelines provisions and existing practice s across the globe inform of codes of corporate governance practice. The extent to which deposit money banks apply the provisions of the codes and to what extent the practice of the recommended corporate governance affect performance can only be known by stakeholders if the deposit money banks make disclosure of their corporate governance practices. Disclosure has been defined as the action of releasing relevant, new, or secret information pertaining to a company, thus making them known and able to influence investment decisions [7].

A review of the disclosure literature shows that prior studies settled heavily on investigating the determinants of disclosures [8] relative to assessing the effect of corporate governance mechanisms on the financial performance of firms.

In the light of the above problems and in view of the vital role of deposit money banks in the economic development of Nigeria this research work studied the effects of disclosure of corporate governance practices on the financial performance of deposit money banks in Nigeria. In the course of its examination, it also provides an exposition on the codes of corporate governance issued by the Central Bank of Nigeria in 2014 and the Securities and Exchange Commission in 2011.

The main purpose of this study is as to explore the relationship between corporate governance disclosures and financial performance of deposit money banks in Nigeria.

\section{A. Research Hypotheses}

The following Research Hypotheses were formulated to achieve the study objectives:

$\mathrm{H}_{\mathrm{O} 1}$ : Corporate Governance disclosure of board of directors has no significant positive effect on return on asset, equity, and earnings per share of deposit money banks in Nigeria.

$\mathrm{H}_{\mathrm{O} 2}$ : Corporate Governance disclosure of risk framework has no significant positive effect on return of asset, equity, and earnings per share of deposit money banks in Nigeria.

$\mathrm{H}_{\mathrm{O} 3}$ : Corporate Governance disclosure of whistle blowing policy has no significant positive effect on return on asset, equity, and earnings per share of deposit money banks in Nigeria.

$\mathrm{H}_{\mathrm{O} 4}$ : Bank Size and Block Shareholdings have no moderating effect on the relationship between corporate governance disclosure and financial performance of deposit money bank of Nigeria.

\section{LITERATURE REVIEW}

The disclosure literature has a long-standing history in accounting both in developed and developing countries.

Mitton studies the impact of corporate governance on the East Asian crisis and finds that the significantly better stock price performance is associated to firms that had indicators of higher disclosure quality [9]. Similarly, Baek, Kang, and Park demonstrate that firms with higher disclosure quality suffer less from the shock arising from Korean crisis [10].

Jiao empirically found a significantly positive association between disclosure rankings and stock performance and market valuation, thereby illustrating the efficacy of highquality disclosures in communicating favorable information about the firms to investors [11]. He presents empirical evidence of the performance benefits of high-quality disclosures, using a United State of America sample of 6534 firms over the period 1982 to 1996.

Using a sample of 122 US manufacturing firms, Botosan demonstrates a significantly positive association between disclosure levels of voluntary information and cost of equity capital [12]. Sengupta finds similar evidence in respect of cost of debts [13].

DeFond, Hann and $\mathrm{Hu}$, report positive market reaction to the disclosure of appointment of financial experts to the audit committees of a sample of US firms [14]. This underscores the importance investors attach to disclosure of corporate governance practices.

Hassan, Romilly, Giorgioni, and Power derived data from a sample of 80 Egyptian non-financial, listed firms listed over the period 1995 to 2002 to examine the value of 
disclosure [15]. They found that voluntary disclosure has a positive but insignificant association with firm value. The authors claim that the lack of statistical significance supports the view that there is a complex interplay of different factors determining the relationship between disclosure and firm value and by extension profitability.

Othman examines the impact of the board structure and process disclosure level on corporate performance based on a sample of 220 companies from 11 Anglophone and Francophone African emerging markets [16]. They provide evidence to show that the board structure and process disclosure level positively affect the corporate performance; with effect being more pronounced amongst firms domiciled in Anglophone African countries than in Francophone African countries. The authors also find the effect is more pronounced amongst financial firms relative to nonfinancial firms. The study provides empirical support to the claims that colonial heritage exerts significant influence on financial reporting in Africa.

Ntim et al examine whether differences in the levels of disclosure of recommended good corporate governance practices as contained in the 2002 King Report can explain observable variations in the market value of South African firms [17]. The regression analysis that incorporates several control variables shows positive association between disclosing corporate governance practices and firm value: with relationship being stronger for shareholder than stakeholder corporate governance provisions. This study excludes the banking firms and focuses on the effects on shareholder and stakeholder's dichotomy.

Achoki, Kule, and Shukla, investigated the effect of voluntary disclosure on the financial performance of commercial banks in Rwanda [12]. The study examined general and strategic disclosure, financial disclosure, forward looking disclosure, and social board disclosure based on the annual reports of 14 banks for the period 2011 to 2016 and reported that variation in financial performance was explained by variation in voluntary disclosure. There was no sensitivity analysis in the study. While the focus of the study is on voluntary disclosure, it considers a wider scope of disclosure since corporate governance practices encompass mandatory and voluntary disclosures and traverse all segments of the firm.

\section{METHODOLOGY}

The study adopts the ex-post facto research design which is suitable where the researcher does not aim to control any of the variables under investigation and uses existing data. The population of this study comprises all the deposit money banks listed on the Nigerian Stock Exchange between 2011 and 2016. The Fact Book of the Nigerian Stock Exchange (2016) showed that fifteen deposit money banks were quoted on the Nigerian Stock Exchange.

The study used content analysis method to analyze corporate governance data disclosed in the annual reports of deposit money banks. Then corporate governance disclosure indices were constructed. The use of content analysis is consistent with the disclosure literature [8]. Krippendorff as cited in Hackson \& Mile states that "content analysis is a research technique for making replicable and valid inferences from data according to their context [22]. It is a method of codifying texts and narratives into various categories based on predefined criteria.

The study adopted econometric model, specifically the ordinary least square method of multiple regressions to explore the relationship between corporate governance disclosure and financial performance. Ordinary Least square multiple regressions relate changes in the dependent variable to variations in the independent variables. Ordinary Least square multiple regressions should be used if the basic regression assumptions are satisfied. The assumptions are:

$\checkmark$ The error term is a random variable with a mean of zero and the underlying relationship between independent and explanatory variables is linear (LINEARITY assumption);

$\checkmark$ The variance of the error term is the same for all the values of the independent variables (HOMOSCEDASTICITY assumption.);

$\checkmark$ The value of the error term is independent (NO SERIAL CORRELATION assumption).

$\checkmark$ The error term is normally distributed (Normality assumption).

\section{RESUlTS}

TABLE 1: REGRESSION RESULTS OF H1A, H1B AND H1C

\begin{tabular}{|c|c|c|c|c|c|c|c|c|c|}
\hline \multirow[b]{2}{*}{$\begin{array}{l}\text { Variable } \\
\text { cgdbd }\end{array}$} & \multicolumn{3}{|c|}{ Model 1a } & \multicolumn{3}{|c|}{ Model 1b } & \multicolumn{3}{|c|}{ Model 1c } \\
\hline & $\begin{array}{c}\text { Coef } \\
82.50444\end{array}$ & $\begin{array}{c}\text { t-stat. } \\
2.30\end{array}$ & $\begin{array}{c}\mathrm{p} \text {-value } \\
0.024\end{array}$ & $\begin{array}{c}\text { Coef } \\
48.0663\end{array}$ & $\begin{array}{c}\text { t-stat. } \\
1.40\end{array}$ & $\begin{array}{c}\text { p-value } \\
0.165\end{array}$ & $\begin{array}{c}\text { Coef } \\
81.7378\end{array}$ & $\begin{array}{c}\text { t-stat. } \\
2.68\end{array}$ & $\begin{array}{c}\mathrm{p} \text {-value } \\
0.009\end{array}$ \\
\hline Sze & 4.566393 & 1.79 & 0.77 & 6.29392 & 2.58 & 0.012 & 7.80340 & 3.60 & 0.001 \\
\hline block & 6.842635 & 0.63 & 0.530 & -5.41191 & -0.52 & 0.603 & -4.60248 & -0.50 & 0.619 \\
\hline Intercept & -119.81 & -2.47 & 0.016 & -126.078 & & -2.71 & -183.239 & -4.44 & 0.000 \\
\hline $\begin{array}{c}\text { Numbero } \\
\text { fobs }\end{array}$ & 78 & & & 78 & & & 78 & & \\
\hline $\mathrm{F}(3,74)$ & 5.29 & & 0.0023 & 6.00 & & 0.0010 & 14.21 & & 0.0000 \\
\hline $\begin{array}{c}\mathrm{R}- \\
\text { squared }\end{array}$ & 0.1767 & & & 0.1957 & & & 0.3654 & & \\
\hline
\end{tabular}

Model 1a shows the coefficient on corporate governance disclosure of board of directors is positive and significant at the $5 \%$ level ( $p$-value $=0.024)$. This is not consistent with the prior expectation. Therefore, $\mathrm{H}_{\mathrm{Ola}}$ is not supported. Result from Model 1b indicates a positive coefficient on corporate governance disclosure of board of directors. Though, the direction is not as predicted the relationship is not statistically significant ( $\mathrm{p}$-value $=0.165)$. Consequently,
$\mathrm{H}_{\mathrm{O} 1 \mathrm{~b}}$ is accepted. Model 1c reports a positive coefficient on corporate governance disclosure of board of directors and this is statistically significant ( $p$-value $=0.009$ ). Since this is not in agreement with the prediction, $\mathrm{H}_{\mathrm{Olc}}$ is rejected.

Bank size and block shareholdings are control variables included in the models. Bank size reveals positive coefficients in all the Models. This "positive relationship is statistically significant in Models $1 \mathrm{~b}$, and $1 \mathrm{c}$ as shown by 
the p-values. While Model 1a records a positive coefficient on block shareholding, Model $1 \mathrm{~b}$ and $1 \mathrm{c}$ reveal negative coefficients. In all the three models the influence of block shareholding is insignificant.

TABLE 2: REGRESSION RESULTS OF H2A, H2B AND H2C

\begin{tabular}{|c|c|c|c|c|c|c|c|c|c|}
\hline \multirow{2}{*}{ Variable } & \multicolumn{3}{|c|}{ Model 2a } & \multicolumn{3}{|c|}{ Model 2b } & \multicolumn{3}{|c|}{ Model 2c } \\
\hline & Coef & t-stat. & $\mathrm{p}$-value & Coef & t-stat. & p-value & Coef & t-stat. & p-value \\
\hline cgdrf & 52.7945 & 1.34 & 0.184 & 18.4150 & 0.49 & 0.623 & 39.7313 & 1.17 & 0.246 \\
\hline Sze & 7.11469 & 3.06 & 0.003 & 7.80092 & 3.54 & 0.001 & 10.3508 & 5.16 & 0.000 \\
\hline block & -3.60259 & -0.34 & 0.738 & -10.8572 & -1.07 & 0.289 & -14.2987 & -1.54 & 0.127 \\
\hline Intercept & -151.651 & -2.60 & 0.011 & -134.929 & -2.44 & 0.017 & -204.904 & -4.07 & 0.000 \\
\hline $\begin{array}{c}\text { Number of } \\
\text { obs }\end{array}$ & 78 & & & 78 & & & 78 & & \\
\hline$F(3,74)$ & 3.97 & & 0.0111 & 5.31 & & 0.0023 & 11.41 & & 0.0000 \\
\hline R-squared & 0.1386 & & & 0.1771 & & & 0.3163 & & \\
\hline
\end{tabular}

Model 2a in Table 2 indicates that corporate governance disclosure of risk framework is positively related to financial performance (proxied by return on assets) of quoted deposit money banks in Nigeria. However, the relationship lacks statistical significance $(\mathrm{p}$-value $=0.184)$. Consequently, $\mathrm{H}_{\mathrm{O} 2 \mathrm{a}}$ is accepted. A further check of Table 2 equally shows a positive coefficient on corporate governance disclosure of risk framework in Model $2 \mathrm{~b}$. Again, this is statistically insignificant ( $p$-value $=0.623$ ). Therefore, $\mathrm{H}_{\mathrm{O} 2 \mathrm{~b}}$ which predicts no positive and significant relationship between corporate governance disclosure of risk framework and financial performance measured by return on equity is accepted. $\mathrm{H}_{\mathrm{O} 2 \mathrm{c}}$ tested the relationship between corporate governance disclosure of risk framework and earnings per share. The result in Model $2 \mathrm{c}$ of Table 2 confirms a positive relationship but this is not significant at any of the conventional levels ( $\mathrm{p}$-value $=0.246$ ). $\mathrm{H}_{\mathrm{O} 2 \mathrm{c}}$ is consequently supported.

TABLE 3: REGRESSION RESULTS OF H3A, H3B AND H3C

\begin{tabular}{ccccccccccc}
\hline \multirow{2}{*}{ Variable } & \multicolumn{3}{c}{ Model 3a } & \multicolumn{3}{c}{ Model 3b } & \multicolumn{3}{c}{ Model 3c } \\
\cline { 2 - 10 } & Coef & t-stat. & p-value & Coef & t-stat. & p-value & Coef & t-stat. & p-value \\
\hline cgdwbp & 49.9861 & 2.28 & 0.025 & 37.4411 & 1.80 & 0.076 & 62.6491 & 3.46 & 0.001 \\
Sze & 3.82300 & 1.41 & 0.164 & 5.29702 & 2.06 & 0.043 & 6.17729 & 2.75 & 0.007 \\
block & 9.04160 & 0.81 & 0.422 & -2.48191 & -0.23 & 0.816 & .177824 & 0.02 & 0.985 \\
Intercept & -75.0545 & -1.48 & 0.144 & -94.1611 & -1.95 & 0.054 & -129.67 & -3.09 & 0.003 \\
Number of & 78 & & & 78 & & & & 78 & & \\
obs & 5.26 & & 0.0024 & 6.52 & & 0.0006 & 16.50 & 0.4008 & \\
F (3, 74) & & & 0.2091 & & & &
\end{tabular}

The three models exhibit excellent fits, and the explanatory power of the models ranges from $18 \%$ to $40 \%$. Model 3a shows a positive coefficient on corporate governance disclosure of whistle blowing policy and this is significant at the $5 \%$ level ( $\mathrm{p}$-value $=0.025) . \mathrm{H}_{\mathrm{O} 3 \mathrm{a}}$ is therefore rejected. Model $3 \mathrm{~b}$ also reveals positive and significant relationship. Consequently, $\mathrm{H}_{\mathrm{O} 3 \mathrm{~b}}$ is not sustained. Model $3 \mathrm{c}$ in Table 3 also reveals that corporate governance disclosure of whistle blowing policy is positively and significantly related to earnings per share. Thus, $\mathrm{H}_{\mathrm{O} 3 \mathrm{c}}$ is rejected.

In respect of the control variables bank size records positive association with the proxies of financial performance but this is only significant in Models $3 \mathrm{~b}$ and 3c. Block shareholdings display mixed results across the Models. While Models $3 \mathrm{a}$ and $3 \mathrm{c}$ record positive coefficient, Model $3 \mathrm{~b}$ document a negative coefficient which indicates inverse relationship. The relationships are not significant.

\section{A. Discussions of Findings}

Model 1a indicates that a one percent increase in the disclosure of corporate governance issues relating to the board of directors is associated with $82 \%$ increase in return on assets, all other variables held constant. In the same manner, earnings per share in Model 1c increases by 82 kobo following a one percent increase in the disclosure level of corporate governance matters bordering on board of directors. A one percent increase in the disclosure of matters of board of directors is associated with $48 \%$ increase in return on equity in Model $1 \mathrm{~b}$, all else held constant. The findings are in agreement with prior studies on the effect of corporate governance and its disclosure on firm performance [17], [12]. Disclosure of corporate governance of board of directors' signals commitment to align with the best international practices. This should incentivize management and staff of the deposit money banks. The result is not surprising since the responsibility for ensuring good corporate governance rests with the 
board. The boards have been blamed for poor performance and corporate failures [23].

Indeed, the regulators usually sack the boards of Nigerian quoted deposit money banks. Sanusi provided evidence of the crucial role of the board of directors in the survival of deposit money banks in Nigeria [3]. The implication of this result is for the boards to be transparent in the management of the deposit money banks to command trust and confidence of the stakeholders.

Disclosure of risk is considered crucial to the survival of the deposit money banks. The results in Model 2a, $2 \mathrm{~b}$ and $2 c$ indicates a positive effect of disclosure of risk framework on firm performance. The effect is not significant, and this may be attributed to inability of risk framework to fully capture the intricate risk factors, for instance risk associated with lending to politically exposed persons. The continuing collapse of deposit money banks in Nigeria seems to give credence to this viewpoint.

Models 3a, 3b and 3c indicate a positive and significant association between the disclosure of whistle blowing policy and the financial performance of the deposit money banks. In Model 3a, for a one percent increase in the disclosure level of the whistle blowing policy, return on assets increases by $50 \%$, ceteris paribus. Models $3 \mathrm{~b}$ and $3 \mathrm{c}$ also provide evidence that increase in the disclosure of the whistle blowing policy is strongly associated with increase in return on equity and earnings per share, all else held constant. This is in agreement with [24] on the value relevance of corporate transparency. Whistle blowing procedure that is transparent can mitigate unethical practices in the banking industry and boost profitability.

Across the Models, the study indicates consistent positive association between bank size and financial performance. This is consistent with the findings in the literature that large firms have better opportunities and can quickly muster sufficient resources to install and implement robust disclosure mechanisms". The role of block shareholdings is inconsistent across the models. This is in agreement with empirical evidence which document mixed findings [25].

\section{CONCLUSION AND RECOMMENDATIONS}

The key objective of this study is to examine the effect of corporate governance disclosure on the financial performance of deposit money banks listed on the Nigerian Stock Exchange from 2011 to 2016. To realize this objective the study developed a disclosure checklist as a research instrument to collect "corporate governance data. The checklist was drawn up based on the provisions of the Code of Corporate Governance for Public Companies in Nigeria, 2011 issued by the Securities and Exchange Commission and the Code of Corporate Governance for Banks and Discount Houses 2014 issued by the Central Bank of Nigeria.

The study used content analysis method to extract corporate governance data from 78 annual reports of thirteen deposit money banks. It then constructed three corporate governance disclosure indices. These are corporate governance disclosure index on board of directors, corporate governance disclosure index on risk framework, and corporate governance disclosure index on whistle blowing policy. It formulated and tested ten hypotheses using ranked ordinary least square method of multiple regressions. As a result of violation of the basic assumptions underlying the use of multiple regressions, the study adopted rank and transformed the dependent variables [26]. Then used the rank transformed data to run the regressions. The following recommendations are made for the deposit money banks, regulatory bodies and researchers.

1. Corporate governance disclosure should be increased in the annual reports of deposit money banks

2. The disclosure should be disaggregated to enhance transparency and understanding.

3. Regulators should revisit the disclosure requirements in the risk framework to ensure that all concerning risks are captured especially in the area of political risks.

4. Deposit money banks should intensify the disclosure of whistle blowing policy.

5. The regulators should intensify enforcement of the disclosure requirements by imposing stiffer penalties on contraventions.

\section{REFERENCES}

[1] Patel, Sandeep A., Amra Balic, and Liliane Bwakira. "Measuring transparency and disclosure at firm-level in emerging markets." Emerging Markets Review 3.4 (2002): 325-337.

[2] Mitei, Hillary Kimutai, and Willy Muturi. "Effect of Board Structure on Financial Performance of Large Agricultural Companies in Trans Nzoia County, Kenya."

[3] Sanusi, L. S. "The Nigerian Banking Industry: what went wrong and the way forward." Delivered at Annual Convocation Ceremony of Bayero University, Kano held on 3.1 (2010): 2010.

[4] Jenkinson, Tim, and Colin Mayer. "The assessment: corporate governance and corporate control." Oxford Review of Economic Policy 8.3 (1992): 1-10.

[5] Hassan, I. E., \& Batool, F. (2016). Voluntary CSR disclosure on company's website: an empirical evidence from Pakistan. International Journal of Learning and Intellectual Capital, 13(4), 289-301.

[6] Dhaliwal, Dan S., et al. "Voluntary nonfinancial disclosure and the cost of equity capital: The initiation of corporate social responsibility reporting." The accounting review 86.1 (2011): 59100.

[7] Malafronte, Irma, Claudio Porzio, and Maria Grazia Starita. "The nature and determinants of disclosure practices in the insurance industry: Evidence from European insurers." International Review of Financial Analysis 45 (2016): 367-382

[8] Barako, Dulacha G. "Determinants of voluntary disclosures in Kenyan companies annual reports." African Journal of Business Management 1.5 (2007)

[9] Mitton, Todd. "A cross-firm analysis of the impact of corporate governance on the East Asian financial crisis." Journal of financial economics 64.2 (2002): 215-241.

[10] Baek, Jae-Seung, Jun-Koo Kang, and Kyung Suh Park. "Corporate governance and firm value: Evidence from the Korean financial crisis." Journal of Financial economics 71.2 (2004): 265-313.

[11] Jiao, Yawen. "Corporate disclosure, market valuation, and firm performance." Financial Management 40.3 (2011): 647-676.

[12] Botosan, Christine A. "Disclosure level and the cost of equity capital." Accounting review (1997): 323-349.

[13] Sengupta, Partha. "Corporate disclosure quality and the cost of debt." Accounting review (1998): 459-474.

[14] DeFond, Mark L., Rebecca N. Hann, and Xuesong Hu. "Does the market value financial expertise on audit committees of boards of directors?." Journal of accounting research 43.2 (2005): 153-193.

[15] Hassan, Omaima AG, et al. "The value relevance of disclosure: Evidence from the emerging capital market of Egypt." The International Journal of Accounting 44.1 (2009): 79-102.

[16] Ameer, Rashid, and Radiah Othman. "Sustainability practices and corporate financial performance: A study based on the top global corporations." Journal of business ethics 108.1 (2012): 61-79. 
[17] Ntim, Collins G., Kwaku K. Opong, and Jo Danbolt. "The relative value relevance of shareholder versus stakeholder corporate governance disclosure policy reforms in South Africa." Corporate Governance: An International Review 20.1 (2012): 84-105.

[18] Gray, Rob, Reza Kouhy, and Simon Lavers. "Constructing a research database of social and environmental reporting by UK companies." Accounting, Auditing \& Accountability Journal (1995).

[19] Hackston, David, and Markus J. Milne. "Some determinants of social and environmental disclosures in New Zealand companies." Accounting, auditing \& accountability journal (1996).

[20] Haniffa, Rozaini Mohd, and Terence E. Cooke. "Culture, corporate governance and disclosure in Malaysian corporations." Abacus 38.3 (2002): 317-349.

[21] Wallace, RS Olusegun, Kamal Naser, and Araceli Mora. "The relationship between the comprehensiveness of corporate annual reports and firm characteristics in Spain." Accounting and business research 25.97 (1994): 41-53.

[22] Krippendorff, Klaus. "Validity in content analysis." (1980): 69

[23] Agrawal, Anup, and Sahiba Chadha. "Corporate governance and accounting scandals." The Journal of Law and Economics 48.2 (2005): 371-406.

[24] Bushman, Robert M., Joseph D. Piotroski, and Abbie J. Smith. "What determines corporate transparency?." Journal of accounting research 42.2 (2004): 207-252.

[25] Isshaq, Zangina, Godfred A. Bokpin, and Joseph Mensah Onumah. "Corporate governance, ownership structure, cash holdings, and firm value on the Ghana Stock Exchange." The Journal of Risk Finance (2009)

[26] Ebirien, Godwin Israel, Gospel Joseph Chukwu, and Mary-Fidelis Chidoziem Abiahu. "Market valuation of related-party loans in the nigerian banking industry." Th 5 Annual International Academic Conference Proceedings, 2019. 2019.

[27] Access Bank" (2016). "Annual Report and Accounts, 2016. Available at https://www.accessbank.com. 